\title{
The King's Prerogatives in the Jordanian Constitutional System
}

\author{
Ahmad al-refaie ${ }^{1}$ \\ ${ }^{1}$ Faculty of Law, Applied Science Private University, Amman, Jordan \\ Correspondence: Ahmad al-refaie, Faculty of Law, Applied Science Private University, Al Arab st. 21-Amman, \\ Jordan. Tel: 962-6560-9999. E-mail: ah.refaie53@gmail.com
}

Received: October 9, 2019

Accepted: November 4, 2019

Online Published: November 28, 2019

doi:10.5539/jpl.v12n4p142

URL: https://doi.org/10.5539/jpl.v12n4p142

\begin{abstract}
Forms of governments vary depending on the standard we want. In terms of the method of access to government, governments are divided into Republican Governments and Royal Governments. Royal government refers to the government by which the governor takes over governance through inheritance for an indefinite period. As for the Republican government it refers to the government by which the governor takes power through elections and for a defined period.

In this paper, we will recognize the King's Prerogatives as stated in the Jordanian Constitution as we will recognize the legislative and executive King's Prerogatives.
\end{abstract}

Keywords: monarchy, constitutional monarchy, royal decree, restricted government, autocratic monarchy, viceregent, crown prince

\section{Introduction}

It is one of the foundations of a Constitutional State to adopt the Principle of Separation of Powers, the aim being to know the competencies of each of these authorities where the Separation of Powers Principle is the means to ensure the achievement of political freedom and democratization. This principle is based on three main points, which are inequality between the three authorities on the one hand and job security among them on the other alongside with functional independence. The relationship between the three authorities is evident in three fundamental respects: First, Structural, which illustrates the overlapping authorities; second, Functional that demonstrates the functional cooperation between authorities and finally dynamic where the balance of competencies is shown in a way, which allows each authority to play its full part.

In this research we will present the King' Prerogatives both Legislative and Executive as stated in the Jordanian Constitution through two topics: the first on the Powers of the King in the field of Executive Authority where the second is on the Powers of the King in the Legislative field.

\section{Powers of the King in the Field of Executive Authority}

The Method section describes in detail how the study was conducted, including conceptual and operational definitions of the variables used in the study, Different types of studies will rely on different methodologies; however, a complete description of the methods used enables the reader to evaluate the appropriateness of your methods and the reliability and the validity of your results, It also permits experienced investigators to replicate the study, If your manuscript is an update of an ongoing or earlier study and the method has been published in detail elsewhere, you may refer the reader to that source and simply give a brief synopsis of the method in this section.

1) The King's Rights: The Jordanian Constitution states that the King is the Head of the State and is immune from any liability and responsibility, the King has prerogatives exercised independently by a Royal Decree. Every such Decree shall be countersigned by the Prime Minister and the Minister or Ministers concerned. The King expresses his concurrence by placing his signature above the said signatures by as stated in Article 40 of the Jordanian Constitution. For example, the Royal Decree concerning military officer's promotions, where the Royal Decree shall be countersigned by the Minister of Defence, in addition to the signature of the Prime Minister, along with the competent minister, and then the King places his signature above the said signatures (Shatnawi, Faisal, 2003). However, there are certain events set out in the constitution, which does not require compliance with the provisions of Article 40 of the Constitution. This includes the King's Prerogatives to appoint 
an Army Commander, the Director of Intelligence and Gendarmerie Commander as stated in Article 127, paragraph 2. This means that the goal is to keep the aforementioned personnel away from politics and independent subordination to the King who independently is responsible for those.

2) The King appoints the Prime Minister and the Ministers and he shall exercise this right with complete freedom.

3) Should the King become unable to exercise his powers on account of illness or if he wishes to leave the country, he shall, before his departure and by a Royal Decree, appoint a Viceregent or a Council of Viceregents to exercise his powers during his absence. The Viceregent or Council of Viceregents shall observe any conditions which may be prescribed in the Royal Decree. If the absence of the King is extended to more than four months and the National Assembly is not in session, the Assembly shall be summoned immediately to consider the matter. The same applies in the event the King is unable to exercise his powers on account of illness, his powers shall be exercised by a Viceregent or Council of Viceregents who the King appoints by a Royal Decree.

4) To appoint Head of the Judicial Council and President of the Constitutional Court and its members.

5) In addition to the aforementioned, the King enjoys other competencies where the King is the Supreme Commander of Armed Forces, he establishes and grants ranks and medals, he declares war and concludes peace and he enjoys the right of issuing special pardons (Omar al-Khadrami and Mustafa al-Adwan, 2002).

\section{The Powers of the King in the Legislative Authority Field}

The Jordanian Constitution grants the King many powers in the legislative field. These powers are as follows (Mustafa Ali Al-Atoum,1999):

1) Ratification and promulgation of laws. The Jordanian Constitution states that every draft law passed by the Senate and the Chamber of Deputies shall be submitted to the King for ratification. Accordingly, no law draft can be issued following its approval by the National Assembly unless ratified by the King. Ratification is part of the legislative process and this constitutional right of the king is not an automatic process. Rather, the King has the right not to approve any draft despite the approval of the Council and within the provisions of Article 93 of the Constitution (Al-Khatib, Noman, 2015), where the issuance is the last step in the enactment of the legislation.

2) The King shall have the powers with respect to summon the National Assembly to an ordinary session or special sessions, defer its meetings, postpone its sessions and extend and adjourn its ordinary session.

Here it is necessary to clarify the meaning of deferment and postponement, where the deferment here means postponing the meeting of the Council and this is stipulated in article 78 of the Constitution, when postponement means that the King has the power to postpone the meetings of the National Assembly. This can only be done for three times, and the duration of the postponements within a regular session may not exceed two months.

3) The King appoints members of the Senate and appoints the Chairman amongst them. The King may dissolve the Senate and the Chamber of Deputies or relieve any Senator of his membership.

There are limitations to this power:

a) If the Chamber of Deputies is dissolved for some reason, it is not permissible to dissolve the new Chamber for the same reasons again.

b) If the Chamber of Deputies dissolves either by the end of its term or by the placement of the government to the king, general elections must be held so that the new council meets in an extraordinary session four months after the date of the council is dissolved at most, and this session shall be considered as a regular session and if the election is not held at the end of the four months, the dissolved Council shall regain all its constitutional powers and meet immediately as if it was never dissolved and continue to work until the new Council is elected.

c) The Extraordinary Session shall not in any case exceed 30th of September and shall be closed on the same day so that the Council may hold its ordinary session on the first day of October.

Therefore, we note that the monarchy in Jordan is a constitutional monarchy, which means that there are three authorities in the political system. Each of these authorities has its constitutionally defined functions, which is headed by the Head of State, the King. These authorities and the King are subject to the Constitution as the Constitution demonstrated the relationship between the authorities in the State and defined the powers of the King exclusively.

\section{Conclusion}

Through this study, we can say that Jordan did not take the presidential system as one of the regular political systems because the king as head of state did not limit the executive function to his hand and there is no severe 
separation of powers. Rather, he adopted the parliamentary system of executive power, i.e., two bodies distinct from each other, namely the Head of State and the Ministry. The king is the head of the state and his role is limited compared to the head of state in the presidential system. In addition, there is cooperation and balance between the legislative and executive authorities.

The Jordanian Constitution did not adopt the Absolute Monarchy, which means limiting powers in the hand of the King even if he is subject to the law, it did not also adopt the Autocratic Monarchy where the King does not abide by any law. Therefore, in Autocratic Monarchy the king does not care about the rights and freedoms of individuals, but rather Constitutional Monarchy, which means the distribution of powers among different bodies where the Constitution defined the competencies of each of these bodies and the King is the head of the state and his Prerogatives are defined in the Constitution as demonstrated in this study.

If we compare the Jordanian monarchy with the British monarchy, we find that the queen in Britain has symbolic political powers and sometimes some of them are actually used, such as holding general elections, in addition to the power to dissolve parliament and convene it and the power to ratify laws.

The Queen has the power to appoint and dismiss ministers, and the Queen retains the power to declare war, although in practice exercised by the Prime Minister and the Parliament.

The Queen is considered above the law and cannot be prosecuted or accountable. Those who study these powers find that they are theoretically broad but limited in practice under the British constitutional custom.

\section{Recommendations}

1) Based on this study, the researcher recommends clarifying what is meant by the King's Prerogatives to conclude treaties and identify the parties to these treaties whether they are private or governmental sectors.

2) The researcher recommends amending the constitution to appoint the Director of Public Security and Civil Defense in the manner in which the Army Commander and the Director of Intelligence are appointed.

\section{Acknowledgments}

I can only extend my heartfelt thanks to the Applied Science Private University for their continuous support.

\section{References}

Al-Atoum. M. A. (1999). The Jordanian Parliamentary System. Amman.

Al-Khatib, N. (2015). The Mediator in Political Systems.

Al-Khadrami, O., \& Al-Adwan, M. (2002). Civic Education. Amman.

Atta, Z. (2009). The Jordanian Political System.

Shatnawi, F. (2003). The Jordanian Constitutional System. Amman.

\section{Copyrights}

Copyright for this article is retained by the author(s), with first publication rights granted to the journal.

This is an open-access article distributed under the terms and conditions of the Creative Commons Attribution license (http://creativecommons.org/licenses/by/4.0/). 